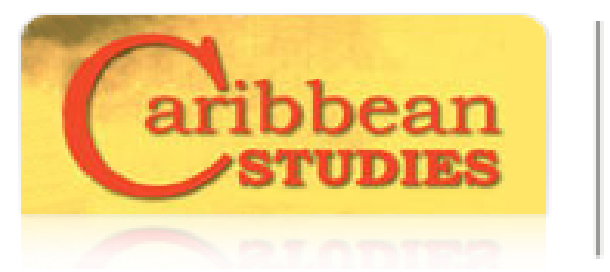

\section{Caribbean Studies}

ISSN: 0008-6533

iec.ics@upr.edu

Instituto de Estudios del Caribe

Puerto Rico

Solá, José O.

Partisanship, Power Contenders, and Colonial Politics in Puerto Rico, 1920s

Caribbean Studies, vol. 38, núm. 1, enero-junio, 2010, pp. 3-35

Instituto de Estudios del Caribe

San Juan, Puerto Rico

Available in: http://www.redalyc.org/articulo.oa?id=39220687001

How to cite

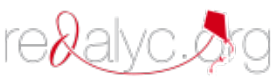

- Complete issue

- More information about this article

Journal's homepage in redalyc.org

Scientific Information System Network of Scientific Journals from Latin America, the Caribbean, Spain and Portugal Non-profit academic project, developed under the open access initiative 


\title{
PARTISANSHIP, POWER CONTENDERS, AND COLONIAL POLITICS IN PUERTO RICO, 1920s
}

\author{
José O. Solá
}

\begin{abstract}
This article explores the political conditions and the reorganization of the political landscape in Puerto Rico during the 1920s. It examines how the rise of a powerful political block with a labor base in the late 1910s brought a sudden change to the political parties (Unión, Republicano, Socialista) in Puerto Rico during the 1920s. The article then shows how Puerto Rico's three dominant political parties began to revise their role as overseers of the colonial apparatus without challenging the American presence, and how they saw the status between the island and the United States resolved. To shed light on the nuances of Puerto Rican politics during the 1920s, this article explains why there was a resurgence of political violence during this decade, and why this violence resembles the episodes of political violence at the beginning of the century. What political and economic transformations had occurred in the island that promoted a political reorganization of the established parties? To fully understand the dynamics of how political partisanship and violence were manifested in Puerto Rico, I will move the narrative to one located within municipal politics. Since Caguas was considered a stronghold of Unionista politics, I examine how political changes during the 1920s unfolded in this municipality.
\end{abstract}

Keywords: Puerto Rico, political violence and partisanship, colonial studies, American imperialism, labor, municipal politics

\section{RESUMEN}

En el presente artículo se exploran las condiciones políticas y la reorganización del ambiente político durante la década del 1920 en Puerto Rico. En el mismo se examina el surgimiento de un poderoso grupo político de base obrera a finales de la década de 1910, el cual produjo un cambio repentino en los partidos políticos de la época (Unión, Republicano, Socialista). A lo largo del artículo se muestra la manera en la que los tres partidos políticos dominantes durante ese periodo comenzaron a revisar sus papeles como testigos del aparato colonial sin desafiar necesariamente la presencia estadounidense, y la manera en la que percibían la resolución del estatus político entre los Estados Unidos y la Isla. Con el objetivo de dar luz a ciertas diferencias existentes en la política de Puerto Rico durante la década del 1920, se analiza la razón por la que hubo un resurgimiento en la violencia 
política durante este periodo y la manera en la que dicha violencia se asemeja a los episodios de violencia política que ocurrieron a principios del siglo XX. ¿Cuáles fueron las transformaciones políticas y económicas que hicieron posible la reorganización de los partidos existentes? Para poder comprender con mayor claridad la manera en la que el partidismo político y la violencia se manifestaron en Puerto Rico, me concentraré en la política de uno de los municipios de la Isla. Debido a que el municipio de Caguas se consideraba uno de los baluartes del Partido Unionista, me detendré a examinar los cambios políticos que ocurrieron en dicha municipalidad durante la década de 1920.

Palabras clave: Puerto Rico, violencia política y partidismo, estudios coloniales, imperialismo estadounidense, fuerza obrera, política municipal

\section{RÉSUMÉ}

Cet article explore les conditions politiques et la réorganisation du paysage politique à Porto Rico durant la décennie de 1920. Il examine comment, vers la fin des années 1910, la montée d'un puissant bloc politique de base ouvrière a bouleversé les partis politiques de l'époque (Unión, Republicano, Socialista). Larticle montre ensuite comment ces trois partis politiques ont remis en question leur rôle en tant que témoins de l'appareil colonial sans remettre en cause la présence américaine pour autant, et comment ils concevaient l'aboutissement de la situation entre l'île et les Etats-Unis. Afin d'expliquer les nuances de la politique portoricaine pendant cette période, nous étudierons les causes de la recrudescence de la violence politique, et nous verrons comment cette violence ressemble à d'autres épisodes de violence qui ont eu lieu au début du siècle. De même, nous présenterons les transformations politiques et économiques qui ont promu la réorganisation politique des partis établis à cette époque-là. Enfin, pour mieux comprendre comment se sont manifestées la dynamique de la partisanerie politique et la violence à Porto Rico, nous nous limiterons à analyser le parcours politique de la municipalité de Caguas, considérée comme l'un des bastions de la politique Unionista, ainsi que les changements politiques qui ont eu lieu dans cette municipalité au cours des années 1920.

Mots-clés: Porto Rico, violence politique et partisane, études coloniales, impérialisme américain, travail, politique municipale

Received: 30 January 2009 Revision received: 9 October 2009 Accepted: 13 October 2009 
fter nearly two decades of civil political discourse, violence,
partisanship, and manipulation again took center stage in
Puerto Rico in 1920 (Negrón-Portillo 1990). The violence that characterized the decade erupted before an important election in November that year when Unionistas intimidated and beat Socialistas in Caguas (Unión Obrera, octubre 14, 1920). ${ }^{1}$ The labor daily Unión Obrera reported that leaflets had been passed throughout the Unionista municipality of Caguas demanding that all the supporters of Partido Unión (hereafter PU) attend a mass rally on October 14, 1920. According to the reporter, fifty Unionistas left their main offices in Caguas chanting "abajo con los obreros" (down with the workers). To the surprise of the Socialistas, who thought the rally was led and mainly comprised of wealthy individuals, it instead consisted of "hombres que si no trabajan no comen" (men, who if they do not work they do not eat). Unión Obrera argued that the workers involved in the rally were not from Caguas. The paper charged that the patricios (patricians), after a series of low attendance at their rallies, were bringing outsiders from the surrounding towns to give the impression that they still had large popular support (Unión Obrera, octubre 14, 1920). This story shows how the patrician leadership of Caguas tried to control and reshape local political outcomes by taking to the streets to create an illusion of dominance over a new powerful contender, Partido Socialista (Socialist Party).

What happened in Caguas was hardly unique. Instead, it illustrates how the rise of a powerful political block grew out of a labor base in the late 1910s to foment dramatic political change in political parties in Puerto Rico in the 1920s. But these groups pushed for change in a community economically and politically tied to the United States. This article examines that shift by asking how these parties revised their role as overseers of the political apparatus without challenging American presence, and how they renegotiated the status between the island and the United States. In the process, the actors in this drama invoked the kinds of violence used to protest political and economic conditions in the early twentieth century. But they utilized that violence to address new grievances and, thus, their protests took on new political meaning. To address these inter-related issues, this article explores how the impact of American capitalism and colonialism dramatically shaped local politics in Puerto Rico in the 1920s.

During the 1920s the United States, as it was doing elsewhere in the Caribbean, "adopted unabashedly a management mode of supervising" Puerto Rican affairs (Pérez Jr. 2003). Forced to deal with a militant labor movement and growing criticism by the United States, a group of leaders on the island began to articulate a new political discourse that was nationalistic and reformist. These leaders formed a new and fragile 
alliance between the landowning interests (Unión Party) and corporate sectors from the Puerto Rican Republican Party. Other leaders called for the full incorporation of the island into the republic as the only way to secure the prosperity of Puerto Ricans and American economic interests. Those calling for the annexation of the island came from the remnants of the Puerto Rican Republican Party and the Socialist Party. These two parties, fearing a victory of the landowning-corporate sectors, joined forces in the Coalition (Coalición) to participate in the elections of November of 1924. The reasons for such political realignments were based on the fear of a working class take over of the political apparatus of the island. More than that, the Coalition hoped that a victory over Unión would end sixteen years of this party's dominance over island politics and secured a new political path based on the modernization of Puerto Rico.

Although the people involved in these contests hoped to shape Puerto Rico's politics writ large, they pursued their goals at the local level, and they played out clearly in towns such as Caguas. The city provides an excellent place to study political contests in Puerto Rico in the 1920s because Caguas was considered a stronghold of the Unionista politics the Coalition sought to change. Unionistas struggled hard to preserve their place in Caguas, and members of the Coalition targeted the city for action to undermine their opponents' power. To fully understand the dynamics of how political partisanship and violence manifested itself in Puerto Rico at the local level, I will examine how political changes during the 1920s unfolded in Caguas.

Certainly the island has had a long history of political violence and intense partisanship. Yet, within the political narrative of Puerto Rico, the 1920s is the least studied decade of the Twentieth Century. This article by no means disregards the scholarship published about this period. ${ }^{2}$ To the contrary, this article builds on it, and one of the main foci of this work is to re-think our understanding of political partisanship, local politics, and American colonialism on the island. During the 1920s the island experienced political realignments among the established parties (Unión, Republicano de Puerto Rico, and Socialista) and between fragments within those parties. Furthermore, the conversion of the Puerto Rican proletariat into a political contender, Partido Socialista (Socialist Party, hereafter PS) during the 1910s had far-reaching implications for the dominant groups (Córdova 1980). The militancy of labor became a potential rival to the landowning segments, the urban bourgeois, and their reformist projects. Yet, the political situation on the island cannot be divorced from the colonial condition in which the local parties functioned under American rule. The multiple forms of United States hegemony in Puerto Rico functioned as a system and profoundly affected the institutional character of the colony. ${ }^{3}$ At the same time it was these 
forms of United States hegemony that allowed for the dominant groups on the island to maintain control over the political apparatus of Puerto Rico. The very function of the metropolis was to shape and preserve elite dominance over the masses without having to get involved in the day-to-day management of municipal or island affairs.

The political transformations that took placed during the 1920s were a reflection of the limits colonial politics, partisanship and economic dislocation of a large sector of the population. The Puerto Rican economy enjoyed a brief boom during the World War I, but fell into a crisis soon after the war ended. Sugarcane cultivation and production dominated the islands' economy and when the world sugar industry went into a depression in the spring of 1920, the island's sugar producers suffered. When they suffered, the rest of the island suffered too. Men lost fortunes and local farmers were left holding their cane, hoping for an increase in the price of sugar. Laborers simply earned less. Yet, these events in the spring of 1920 had their origins during the first years of the century when the insular economy began to concentrate its energies in the cultivation of sugarcane as it became a protected crop under U.S. tariff system (Ayala and Bernabe 2007; Scarano 1993). The expansion of the sugar economy during those early years after the U.S. take over of the island opened new conditions for local sugar interests (centralistas and colonos) to benefit and to emerge as the new dominant political force in the island. Until 1920, Puerto Rican local sugar producers manufactured about $65 \%$ to $75 \%$ percent of the sugar processed in the island, and the colonos controlled $75 \%$ of the land cultivated with cane (Giusti Cordero 1996:213).

The increase in sugar production changed local political conditions. Puerto Ricans moved away from coffee production to sugar after 1898 and, as they did so, they reshaped their communities. Cities in the interior of the island saw their populations decline while cities on the coast saw their populations increase. The population shift resulted in a shift in power because politically powerful actors moved from the interior to the coast and because politically motivated men in the coastal towns turned their new economic prosperity into political clout. To express and push their political agenda, these men organized new lobbying groups such as the Association of Puerto Rican Sugar Producers.

Laborers also moved, and were moved, away from the centers of coffee production to the sugarcane fields, and the relocation offered them the chance to change their political conditions too. After 1898, laborers in sugarcane regions found new spaces to voice their concerns and demands for better wages and justice. Under Santiago Iglesias, the Federación Libre de Trabajadores (hereafter FLT), began a campaign to organize tobacco or cigar factory and field workers, sugarcane cutters 
and mill workers and dockworkers during the first decade of the century. From 1903 to 1915 the membership of the FLT increased from 5,500 to 8,700. (Ayala and Bernabe 2007:63). However, according to Ayala and Bernabe the membership of the FLT tripled after World War I. By 1920 the FLT counted 28,000 members (2007:64). As they grew in numbers and gained political power, organized sugarcane workers became both a political and a social threat to the political and economic rulers of the island. That threat became real when workers took action in the run up to the elections of $1920 .{ }^{4}$

\section{The Elections of 1920: Violence and the Re-organization of the Political Parties}

The general election took place November 2, 1920 under the watchful eye of Governor Arthur Yager, who had served as the American governor since 1914. The three leading political parties were Unión, Republicano, and Socialista. ${ }^{5}$ Union, the dominant party on the island since 1904, had maintained good relations with the American governors, which in turn had benefited this party through the nomination of many of their members to political positions within the colonial government. The colonial collaboration between the Americans and the Unionistas forced the Socialistas to approach the Republicanos in order to negotiate an electoral coalition. However, the Socialistas opted out of this suggestion just prior to the election (Pagán 1959, 1:196-199).

After the invasion of 1898, Puerto Rican politics developed into a competition for control of the legislative branch and municipal assemblies. The winners hoped to influence the political discourse with the North American officials and to maintain accessibility for local products into the American market. Power contenders observed the protocol and rituals of political competition, but underneath this orchestrated theater wide-scale coercion and violence against the electorate were routine. Those in power at the national level distributed favors to their party followers. At the local level, an election was still a no-holds-barred contest. Competing factions each tried to cast as many ballots as possible-per person-while preventing the other side from doing the same. In the rural barrios of the municipalities, the landowners controlled their workers when the elections came. They delivered the votes as long as those in power continued to be in power.

American colonial officials were expected to administer the island and look after the welfare of American investors and the natives. In this atmosphere, American officials tolerated, within acceptable parameters, the violence that took place prior to the elections. In the eyes of the Americans, this violence was to be dealt with by the local police. Puerto 
Rican power contenders accepted the reality of American hegemony; they worked to re-enforce it through collaboration. But at every opportunity, locals exploited the control they exercised over municipal affairs to enforce partisan politics.

Puerto Rican politics observed all external proprieties of electoral competition supported by outside democratic influence. The platforms of the political parties provided a window into how each viewed this idealized political discourse within a civilized nation. American tutelage has shown to Puerto Rican power contenders that in order to further their interest, they must provide a rational argument about the goals of their party to the masses. Yet, through a careful reading of these platforms one can discover a subtext that shows how Puerto Ricans understood American hegemony. Furthermore, at the same time the texts show how these political parties manipulated language to engage their followers.

\section{Platforms, Partisanship and Political Enemies}

The small but important electoral victory of Santiago Iglesias, president of PS during the 1917 election for the Puerto Rican Senate, was of great concern to the other two parties, Unión and Republicano. Also the growth in the militancy and electoral power of the workers placed the Unión and Republicano in the defensive. According to Francisco Scarano, the impact of the Socialistas has to be contextualized within a larger historical movement: the triumph of the Russian Revolution and the rise of a red scare throughout the United States and Puerto Rico (Scarano 1993:655). In 1919 members of the Socialista Party began calling for the creation of an independent republic (Ayala and Bernabe 2007:64). This radical position pushed the Unión and Republicano parties to reemphasize their commitment to solve the plight of the workers and to find solutions to the political status of the island.

In the process of showing their rank and file the party's commitment to solve Puerto Rico's problems, Unión emphasized at their 1920 assembly their commitment to the United States and collaboration with the metropolis to resolve the island's problems (La Democracia, septiembre 14, 1920). Unión called for the expansion of the Jones Act so eventually the United States would allow, under their protection, the creation of an autonomous government where popular sovereignty would allow Puerto Ricans to elect their government. To deal with the emerging red threat, Unión's platform declared that it would support neither anarchist doctrines nor social systems that disturbed the harmony and brotherhood among all social elements on the island. At the same time, Unión declared that to stop the imposition of such a system, the government needed to work to resolve the proletariat's plight. Unión's platform of 
the 1920s called for an increase in minimum wage, housing for workers, access to affordable food and clothing, and education (La Democracia, septiembre 14,1920$){ }^{6}$

The Partido Republicano de Puerto Rico (hereafter PRRep) constructed their platform as one where they have struggled to maintain the political freedom of Puerto Ricans (Bothwell González 1979:370-382). According to this party platform, the political freedoms and patriotism of Puerto Ricans and Republicanos had been denied by the Unionistas during the past sixteen years. Republicanos argued that they had been persecuted and removed from political appointments by Unionistas. According to the published platform, they were living a "via crucis" since the 1906 election, which they lost by a landslide. According to the Republicanos, during the previous sixteen years Puerto Rico had taken down a path where the ultimate goal was the slowing down of the island's progress by a political elite entrenched in paternalist and anti-modern views masked by slogans of the great Puerto Rican family (Bothwell González 1979:371).

In the process of blaming Unión for the island status, the Republicanos constructed an alternative outcome for the island. In their plan the "true independence of the island, the recognition of the sovereignty of the people will be guaranteed through Puerto Rico's incorporation into the American union, in which free and sovereign republics are integrated under a common and limited association" (Bothwell González 1979:371). The Republicanos spoke of statehood of the island as the only way to safeguard their rights as a political party as well as the rights of the people. However, their interpretation of the United States as a republic composed of a union between free and sovereign states either was a deliberate manipulation of the reality to guarantee support of individuals who saw American culture as a threat to the island, or it was a complete misunderstanding of American federalism. The platform continued to blame Unión for the problems the laboring classes were suffering on the island. They argued that Unión was responsible, not the Republicanos, because their party had not been given the opportunity to deal with the problems afflicting the laboring groups. Furthermore, the Republicano platform went on to criticize the laboring groups for forming a party based on class interests not on the interests of Puerto Rico as whole (Bothwell González 1979:372).

For the PS, both Union and Republicanos were the enemies of the laboring groups. The PS asserted that these parties platforms were only a front for the protection of the capitalists whose ultimate goal was to control the natural wealth of the island through the political apparatus so only a minority of the people could benefit (Bothwell González 1979:362-369). At the heart of the PS was the welfare of the Puerto Rican 
workers. Yet at the same time, their platform constructed a worker who was a victim of economic conditions outside their control. The platform also described the workers (in the field, factory and shops) as a group reduced to a semi-savage condition, slaves who were deprived of light, air and food (Bothwell González 1979:362).

Each of the parties on the island during the 1920 electoral campaign portrayed their opposition as either introducing foreign and threatening ideas, or unable to bring about change due to their close relationship with the colonial system. Both Unión and Republicanos addressed the issue of the laboring classes by either opposing anarchist views or forming a class-based party. They saw this action as disruptive and threatening to the economic and social stability of the island. Socialistas, while presenting themselves as the party of the laboring groups, described the workers' as slaves and semi-savages. This could have potentially backfired if the workers saw this as an attack on them. Unión and Republicanos platforms addressed the workers without having to reduce them to uncivilized savages. The platforms gave the rank and file of each party the language to describe the enemy, whether they were servants to capitalism or anarchists trying to bring class warfare to Puerto Rico, or elitist Puerto Ricans whose desire was to maintain total control over the island and prevent progress and modernization.

\section{Caguas and Partisan Politics during the Election of 1920}

As Election Day got closer in Puerto Rico, signs of political intimidation began to surface. The main target of political intimidation was Socialistas and their followers. According to Francisco Scarano (1993:655), there is no consensus among historians about the sudden fear towards the socialist surge but it is clear that the numerical increase of unionized workers led to a "red scare" on the island. The militancy of the workers was not ignored by the Unionistas and Republicanos but since Unión was the dominant party most of the violence throughout the island was perpetrated by their rank-and-file. The labor strife of the years between 1915 and 1917 against the sugar sector (farmers-colonos and centralistas - mill owners), demonstrated to this economic sector that they had lost control over the labor force and that they were having difficulties keeping the FLT from promoting their agenda. Fearing further loss of political as well as social control over the laboring groups, Unión used their rank-and-file to put down the red tide.

On October 15, the Socialistas celebrated a mass rally in Caguas at the street corner locally known as White Rabbit (Conejo Blanco). The marchers left the Socialista Club and after marching through the city, arrived at the grandstand that was decorated with red ribbons. Waiting 
for them at the grandstand was a city employee with a Unionista political mob. The Unionista demanded that the speaker step down. Pedro Cotto, the Socialista speaker, stated that they were given permission to hold the rally and that unlike the Unionista rallies, in Socialistas rallies no one was ever denied the right to speak. The turba (political mob) then hit Cotto and the police who were accompanying the mob arrested Cotto. Moments later, more policemen and turbas returned to the grandstand, aiming their clubs to see if any other Socialista wanted to help Cotto. Later on, Ignacio Gonzales, another Socialista, was attacked by a Unionista mob (Unión Obrera, octubre 21, 1920).

The repression of Socialistas by Unionistas continued for the duration of the electoral campaign of 1920. Clearly, the resurgence of political violence during the campaign of 1920 echoes the violence perpetuated by Republicano mobs against the Federales during the electoral campaign of 1900 and 1902 (Negrón-Portillo 1990). However, unlike the political violence during the first two elections of the century which was driven by political rivalry between two parties with similar political goals, the violence of 1920 was driven by class issues and the loss of paternalistic control over the laboring groups in the island. Furthermore, we must take into consideration the economic juncture the island was facing during that year. The sudden recession caused by the drop in world price for sugar placed the sugar interest in the island on the defensive. Until that election Unión had maintained dominance over the political landscape of the island without having hegemonic control of the system.

The day before the election, November 2, Unionistas celebrated a mass rally that took on a carnavalesque flavor. Early in the morning the landowners began to arrive in Caguas from their barrios followed by their "colorful people." Agregados (resident workers) got dressed in "the colors of the party that their boss supported." Other landowners whose properties were located in more distant regions of the municipality had arrived the day before. According to Unión Obrera on November 3, the landowners placed their agregados in barracks where they were given large quantities of alcohol, food and entertainment until it was their time to vote.

The results of the 1920 election showed that both Unión and Republicanos lost control over the laboring groups. At the same time, the electoral victory in 1920 by the Socialistas confirmed the fears of many: the rise of a new political power contender. The PS won 8 municipalities, elected one senator and three representatives, and obtained more votes than the PRRep in three senate districts. The PU received 126,440 votes, PRep 63,845 votes, and PS 59,140 votes or $23 \%$ of the total votes (Pagán 1959, 1:199). The PS dominated eastern coastal area of Puerto Rico, from Río Grande to Yabucoa until the 1930s (Ayala and 
Bernabe 2007:65). In Caguas, Union won the election with 5,031 votes, the Socialistas' party was second with 1,210 votes, and the Republicanos earned 310 votes (Unión Obrera, noviembre 4, 1920). Socialistas were able to elect two workers to the Assembly of Caguas, Nicolás Rodríguez García and Alfonso Torres (Unión Obrera, enero 20, 1921:2). ${ }^{7}$ Some of the Assembly members were the same group of Unionistas who, during the election had begun the campaign of terror against the Socialista supporters.

\section{A Short Lived Victory: Post-Election Politics in Caguas.}

The victories by PS in Caguas were met with a wave of resistance, violence and partisanship that eventually led to the removal of the Socialistas from the assembly. In Caguas the PS faced an assembly controlled by the PU, who were mostly colonos (sugar farmers), and whose main goal was to maintain the sugar sector's political control of the municipality and the island government. After the inauguration of the new Assembly on January 10, 1921, Socialista assemblymen faced strong opposition in the municipal government. For the next six months, the Socialista minority tried to implement a series of ordinances that would directly help the working masses of Caguas. However, the Unionistas dominated the Assembly and the administration was slow to implement the ordinances. On July 15, 1921 Unión Obrera accused the majority of the assemblymen who were from wealthy sectors (elementos acomoda$d o s$ ) of stalling because they were the ones who would be directly and negatively affected by these ordinances. The Unionistas in the Assembly attacked the Socialistas in two ways-by manipulating the political inexperience of the newly elected pro-labor members and by blaming them for inciting and supporting the cane strikes. During the month of December 1920, the FLT began to rally and prepare the cane workers for an upcoming strike in January 1921. An example of the violence deployed by Unionistas is highlighted by a report in Unión Obrera, dated March 24. According to this newspaper, Juan Marcano was arrested and sentenced to four months and fined $\$ 50$ for his actions against a strikebreaker. The police arrested Marcano who supposedly threatened Antonio Flores, the strikebreaker, with a pistol by saying "if I see you tomorrow at work I will blow your brains out for being a strikebreaker" (Unión Obrera, marzo 24, 1921). ${ }^{8}$ Socialistas were accused during the first months in office of supporting the strikes at the Central Santa Juana. The pro-labor members blamed the Unionistas for violent confrontations between the police and the strikers and for the jailing of cane workers. The antagonism between the Socialistas and the Unionistas continued for the next two years. By 1923, the colonos and their supporters had finally forced the Socialistas 
out of the Assembly (AHMC, Sección: Gobierno, Subsección: Asamblea Municipal, Serie: Correspondencia, Caja: 18, Años: 1922-24).

While the political parties dealt with the aftermath of the election, the current governor, Arthur Yager, resigned and was replaced by E. Mont Reily. With the appointment of Reily came a sudden end to the cordial relations between PU and the Governor's mansion. During his inaugural address, he insisted that the United States' flag ("Old Glory") should be the only flag used over the island. Additionally, he placed several mainland politicians in prominent positions in the Puerto Rican government. It was this strong Americanism, imposition of American politicians instead of Puerto Ricans in prominent positions, and Reily's overall attitude towards sectors of the dominant forces that led to conflict. Prior to the appointment of Reily, Governor Yager, in collaboration with Horace M. Towner (R-Iowa), president of the House Committee on Insular Affairs, "advised Partido Unión leaders in 1921 that there is legitimate ground for a larger measure of self-government, but that has been greatly injured by the active independence propaganda"(Ayala and Bernabe 2007:58). This recommendation set the stage for the incoming struggle within the Unionista ranks. From the standpoint of the new governor, independence had no place within the political discourse on the island. As governor, Reily announced that he would not appoint PU members to government posts as long as the party had an independence statement in their platform. This set the stage for confrontation between the governor and the PU. A series of letters sent by Reily to Washington documented his dislike of the PU and the pro-Independence sector on the island. Reily was a strong supporter of "Americanism", the introduction of some aspects of mainland United States culture and its advancement over native Puerto Rican culture.

Reily reintroduced a United States presence that claimed a general proprietary authority over the island and the specific responsibility of the colonial administrators to control, acculturate and protect the properties of Americans and their possessions. Early on in his administration, Reily began discussing his conflict with the PU through letters to the Bureau of Insular Affairs. In a letter dated 13 August 1921, Reily stated that "Puerto Ricans, that is the group that follows Barceló, the Partido Unionista Independista, is trying to create trouble due to my strong opposition to independence" (Bothwell González1979:316-317). He also argued that he had defeated them so far despite the fact that they had tried to send several delegations to discuss the removal of members of the party from government positions. This letter clearly shows that the clash between Barceló and Reily was about power and who controls the island. The days of collaboration were gone. Reily insisted that he alone was going to make the decision about who to nominate or appoint, and 
that when the Senate came to session, if they did not ratify his appointments, he would not continue their term. Reily continued his attacks on the PU, specifically against Barceló and what he called the corrupted officials controlling the insular government. At all times he argued that the majority of the people, both Americans and Puerto Ricans, were behind his policies (Bothwell González 1979:318-321).

By 1922, the Governor's attacks on the PU peaked. On September 23 the PU gathered their followers and party officials to draft a resolution condemning the governor and to ask Washington and President Harding to remove Reily. According to the resolution, the governor represented a "threat to the honor and dignity of the people" of Puerto Rico (El Mundo, septiembre 25, 1922). The resolution carefully used a language in which they, the PU and the people of Puerto Rico, have benefited from the peaceful relationship between the island and United States. Furthermore, according to the Unionista leadership under the careful tutelage of the American administrators the island had reached a political maturity. Despite the fact that Puerto Ricans are a people who love and admire the institutions of American democracy, under the governorship of Reily, the island had been subjected to an authoritarian regime where the rights of the people and their representatives were violated. This regime was transforming Puerto Ricans into a conquered people with no right to aspire to the benefits and privileges guaranteed under their American citizenship. In addition to this resolution Puerto Rican Resident Commissioner Felix Córdova Dávila sent a cable to the President in which he petitioned to begin the process of impeachment against Reily (El Mundo, septiembre 25, 1922). Under pressure to leave office, and suffering from an illness Reily had contracted during a return visit to the continental United States, the Governor resigned in 1923. He was succeeded by U.S. Representative Horace Mann Towner, the Chairman of the House Committee on Insular Affairs, which had jurisdiction over Puerto Rico.

After 1920, the issue of women suffrage became central in political platform for the Socialistas. While the origins of the women's suffrage movement were squarely middle-class, once the Socialistas incorporated into their platform they were able to engender a new political threat against the Unionistas and Republicanos. Antonio Barceló, leader of the Unión, feared that the vote of 300,000 poor, illiterate and exploited women would clearly favor the Socialistas (Ayala and Bernabe 2007:69). Unionistas and Republicanos understood what was at stake for the election of 1924, their control over the political apparatus of the colony. The dominant party, Unión, had survived the attacks by the previous governor, but the prospect of wining the next election was in doubt. Unión had lost control over the male laboring class but the extension of the right 
to vote to their daughters, mothers, and wives clearly points to the end of their patriarchal control over the island. Appealing to women within their class, Unión hoped they would oppose universal suffrage. By 1924 the women's movement in the island had split between those supporting universal suffrage and those opposing it. Anti-socialist fears allow the dominant parties to avert a possible electoral defeat (Scarano 1993). Yet, it was clear that crisis within the parties was emerging. Whether it was driven by attacks by colonial officials, internal fighting, loss of control over the laboring classes or the inability to defeat the opposition, by 1923-24 it was clear that the three political parties needed to rethink their agendas and strategies for coming elections.

\section{The Free Associated State and the Collapse of the Independence Wing of the Unionistas}

As the Unionistas fought Governor Reily during 1922, a transformation took placed with this party. Under the leadership of Antonio Barceló and with the help of Congressman Philip Campell (R-Kansas), a project was presented to create a new Organic Act for Puerto Rico. First the $\mathrm{PU}$, yielding to pressure, removed independence from its program and adopted the idea of a "free associated state" or Estado Libre Asociado, hereafter ELA (Ayala and Bernabe 2007:59; Pagán 1959:221; Bothwell González 1979:339-348). On February 11, 1922 the PU met in an assembly and adopted the ELA as the solution to the Puerto Rican status question. The declaration of principles stated that at this moment, a compact between the two nations already existed guaranteeing the creation of an association or a free associated state. The creation of this new form of governance would not alter the governmental structure between the island and the US; it only guaranteed the continuation of such permanent relation. The goal of ELA, according to the PU, was to extend to Puerto Ricans, as United States citizens, the right to elect their own officials including their governor. Clearly the drafting of the proposal was closely connected to the ongoing battles between Barceló and Reily. If Congress approved such changes, the Unionistas would get rid of governors such as Reily by electing a Puerto Rican to the island's executive branch. For the Republicanos, the Campbell project was unacceptable due in part to their inability since 1904 election to win a majority. The PRRep also fought the project because it did not guarantee the entrance of Puerto Rico into the union as a territory, which would then lead to the island's acceptance as an equal state. The Unionistas, as the dominant party on the island, saw themselves as a political group through which political demands and changes would be articulated. 


\section{The Realignments in the Political Landscape of Puerto Rico}

As the campaign for the 1924 election gathered force, power contenders on the island began to reassess their political futures. For the PS, the years between 1920 and 1923 led to a decline in support. What were the causes for this decline in support? Were they structural or were they the result of the party's failure to deliver the changes promised to supporters during the past election and that economic conditions did not favor organized workers at that moment. The drop in the price of sugar in 1920 was the beginning of the end of the "danza de los millones," a period of increased price of sugar due to the war in Europe. The sudden economic crisis plunged the island into turmoil that lead to a spike of unemployment that drove many workers to immigrate to places such as New York and Connecticut (Iglesias 1998). Furthermore, the years of political activity between FLT and Socialista leaders transformed their roles from those of labor organizers and spokesmen for the workers to those of bureaucrats and politicians. By entering into politics labor organizers began to measure their success in the following terms: what positions they were gaining in the assemblies, legislature and executive offices and how far they were moving up the ladder (Scarano 1993:657). Militant labor organizers, the potential rivals to the dominant parties, had been co-opted by bourgeois politics. In the process, the PS began to move to the center of the political spectrum and openly reaffirmed its pro-statehood position in 1923 (Programa del Partido Socialista de Puerto Rico 1923). However, the PS did not capitulate in their mission. They continued to be critical of the latifundios, the capitalists, and the politics that violate the rights of the people. They understood that to defeat the Unionistas they would have to join forces with the Republicanos.

Beginning in 1923, there were rumors that Socialistas and Republicanos had begun a dialogue to explore the possibility of forming an alliance to defeat the Unionistas at the next election-the 1924 election. These rumors forced the PU and PRRep, especially the landed elements of those two parties, to begin a dialogue regarding the possibility of joining forces to prevent Socialistas and urban professional groups from the Republicano from forming a coalition.

In early 1924 a series of ideological conflicts engendered a schism within the PU. A segment of their party left to form a new political organization after the PU approved of ELA as the guiding principle for their political platform. Since the party rejected the independence option of their platform in favor of the ELA, radical independence elements within PU began the process of creating their own political organization, the Partido Nacionalista, the Nationalist Party, hereafter PN. The first leadership of this party came from the ranks of professional and 
commercial elements more aligned with the Puerto Rican elite. It took years before the PN became the radical party known to historians and Puerto Ricans. This transformation took place when a young lawyer took the presidency of the party, Pedro Albizu Campos.

In 1924 the Unionista leader Antonio Barceló and other political officials from the PRRep and PS traveled to Washington to discuss Puerto Rico's political status. In Washington, Barceló was quoted in the New York press expressing pro-American sentiments and stating that Puerto Ricans were happy to be American citizens. Furthermore, the president of the PU stated that Puerto Ricans would only accept either statehood or independence as a final solution to the colonial condition of the island.

Upon returning from D.C., Antonio Barceló and José Tous Soto, a Republicano leader, presented to their rank and file the new political project. The manifesto they issued was a detailed explanation of a new alliance between PU and PRRep. The section on agriculture called for the solution to the agrarian crisis by redistributing land to encourage the re-emergence of individual farming and reduction of the latifundium. Most of the Republicanos (those who followed Barbosa's pro-annexation ideas) criticized Tous Soto and rejected the new political association called Partido Alianza (NARA Record Group 350, 719-A, Entry 5, Box 112; Pagán 1959:201-202, 231-232). Republicano leaders such as Rafael Martínez Nadal, Roberto H. Todd, Manuel F. Rossy, José Gómez Brioso, Fernando J. Géigel Polanco, Pedro Juan Barbosa and others directed their protests to the people hoping to get subaltern support. Many in the PRRep considered Tous Soto an opportunistic lawyer who represented the interests of the American sugar trust and who felt more comfortable forging an alliance with the Unionistas than with the Socialistas. Alianza eventually united the landed sectors in Puerto Rico for the first time since 1898.

Santiago Iglesias and the Socialistas during this time were also trying to forge a coalition with elements from the PRep. The Socialistas and Republicanos only agreed on two issues-the annexation of Puerto Rico by the U.S. and their dislike and distrust of the landed sectors on the island. On May 14, 1924, Iglesias sent a letter to Samuel Gompers explaining to the labor leader that the Partido Alianza was the unification of big business and of the intellectuals of the Unión and Republicano parties. Iglesias saw this alliance as a conspiracy to destroy the labor movement and the workers' political power in Puerto Rico. In regard to Tous Soto he told Gompers the following:

As you know, Mr. Tous Soto was the one who was continuously seeking coalition with us, between the Republican and the Socialist parties, so as to engraft on the island true Americanization, in opposition to the 
independentistas of the Unionist Party of Mr. Barceló. Now he (Mr. Tous Soto) has changed his mind, and has formed an alliance with the Unionists, seeking the dissolution of the Socialist Party, hoping at the same time to win the cooperation of the American Federation of Labor on the island and in Washington in order to benefit the Alliance Party (NARA, Record Group 350, 719-A, Entry 5, Box 112).

According to Santiago Iglesias, Alianza was forged to prevent the Socialistas victory in the 1924 election. Iglesias predicted the Socialistas were going to win it. The new political organization that would lead them to victory was called Partido Coalición.

\section{Political Realignments at the Local Level: Caguas}

The few Republicanos in Caguas, such as Julio Janer, a colono (sugar farmer), joined José Tous Soto by affiliating with Unión to create the Alianza. Other Republicanos like Luis Fortuño joined the Coalición (Coalition) which had united with the Socialistas. The radical sectors of the Unión followed Luis García Casanova and Erasmo Velázquez who led the local chapter of the Partido Nacionalista (AHMC, Sección: Gobierno, Subsección: Asamblea Municipal, Serie: Correspondencia, Caja: 18, Años: 1922-24). ${ }^{9}$ As in the rest of the island, the landed sectors came together under the Alianza, and Coalición brought together the professional sectors and laboring elements.

In Caguas, conflicts within Alianza began to surface in July of 1924 when the mayor, Juan Jiménez García (a colono), presented his resignation to the Assembly. Brewing conflicts between the different sectors of the dominant party appear to be the cause of the resignation. The local committee of the Unión then nominated Domingo Lasa Quiñones (colono) for the position (AHMC, Sección: Gobierno, Subsección: Asamblea Municipal, Serie: Correspondencia, Caja: 18, Años: 1922-24). ${ }^{10}$ At that moment, this local section of Unión was part of Alianza, whose leadership also supported the nomination. However, two delegates of the Assembly, Joaquín Vendrell Joubert, lawyer for Central Defensa, and Miguel Rodríguez de Jesús voted against the motion presented to the governing body. The two delegates argued on the floor that they did not endorse the candidate since Alianza was not an official party and therefore did not have the right to nominate candidates for the vacant positions. The arguments by Vendrell Joubert and Rodríguez de Jesús were correct because the PU and PRRep still existed as parties but the votes cast for each party would be combined as the total number of votes for Alianza. Therefore, political nominations had to be done by members of the existing parties not the new organization. A week later, Domingo Lasa Quiñones submitted his resignation. Once again, to deal with the 
vacant position, the local committee of the Alianza Puertorriqueña held a meeting on July 23 at which they nominated Oscar Lizardi as a candidate for the position (AHMC, Sección: Gobierno, Subsección: Asamblea Municipal, Serie: Correspondencia, Caja: 18, Años: 1922-24). ${ }^{11}$

\section{The Elections of 1924 and the Emergence of the Fuerzas Vivas}

The election took place on November 4 and the predictions by Santiago Iglesias that the Coalición would be victorious fell short. Alianza won by an overwhelming majority. Alianza obtained 163,041 votes (the PU obtained 132,755 votes, PRP 30,286) and Coalición obtained 90,679 (the PS obtained 56,103 votes and the Republicanos Puros 34,576). Alianza also won the election in Caguas with 4,724 votes. Coalición followed Alianza with 1,763 votes and then the Nacionalistas with 183 votes (Pagán 1959, 1: 331-332). Overall the PU had increased the number of supporters by 8,000 since the 1920 election while the PS lost over 3,000 supporters. Coalición elected only two senators at large and three representatives.

Capitalizing on the victory of Alianza, Governor Towner worked to restructure the economic policies of the colonial government and attempted to pass stiffer tax laws against the corporations in Puerto Rico, as well as a new national income tax. The Unionistas in the Alianza approved this measure, but the Republicanos were outraged. Previous reforms in the colonial regime had failed due to insufficient funds. Antonio Barceló and Governor Towner knew that many Puerto Ricans on the island under-assessed their property and, in order to generate the necessary revenues to be able to begin a series of reforms, they favored a revision of the property tax. For the American corporations, sugar farmers, and centralistas, this would mean an increase in their taxes, and it was therefore not acceptable.

Reacting to these intrusive management modes, different pressure groups began to oppose the measures. The most vocal of these were the Cámara de Comercio (Chamber of Commerce), the Association of Puerto Rican Sugar Producers (APAPR) and Asociación de Agricultores (Farmers Association). These three groups designated as their leader and spokesperson Eduardo Giorgetti, a Unionista and centralista, to voice their opposition to the new property tax. Giorgetti was the ex-President of the Partido Unión, one of the original founders of APAPR, a member of the Asociación de Agricultores, and an old friend and collaborator of Luis Muñoz Rivera. Under pressure, Governor Towner rejected the tax proposal, leaving Barceló to deal with the dissatisfied farmers of the Alianza.

As consequence of the debate over property taxes within Alianza, 
an internal coalition known throughout Puerto Rico as las Fuerzas Vivas (Vital Forces) was formed with the goal of creating a new nationalist reform movement on the island. The members of this coalition belonged to the Cámara de Comercio (Chamber of Commerce), the Asociación de Productores de Azúcar de Puerto Rico (APAPR) and the newly formed Asociación de Agricultores (Farmers Association). ${ }^{12}$ This powerful pressure group represented local capitalists, advocated entirely national goals, and most of all demanded state support of interests that were solely Puerto Rican. These social forces represented the foremost pressure groups committed to the defense of national interests. The Fuerzas Vivas was a coalition of voluntary class groups that joined to formulate, advocate for, and organize a political strategy within the new political party-Partido Alianza. This coalition advocated free commerce and democratic capitalism that would confront the totalitarian tendencies of the Coalición. The enemies of the Fuerzas Vivas were the foreign capitalists, including the American sugar trusts, professional bureaucrats, educated peasants and the labor movement. They were critical of Puerto Rico's growing dependence on and control by American capital of the economy, and especially of the sugar industry (Giusti-Cordero 1996:211-224).

As the dominant sector of the Alianza, landowners (especially colonos and centralistas) began to question the dependent economic situation of the island, and this sector also demanded more political autonomy for the island. Agrarianism as a discourse in the Alianza was anti-liberal and nationalist in its tone (Pagán 1959, 1:233). ${ }^{13}$ This discourse reflected the old, pre-1898 agrarian discourse under the Spanish regime but now with corporativist innovations.

One of the most influential and powerful organizations within the Fuerzas Vivas was the Farmers Association (Asociación de Agricultores), founded on June 27, 1924. There were forty-seven members that signed the original constitution of the organization (AAPR 1925:7). The association expanded quickly and six months later it had thirty-three local chapters. These chapters proceeded to elect the national Board of Directors for the Farmers Association (AAPR 1936:25). ${ }^{14}$ The Farmers Association had members who were mayors and assemblymen, such as Cándido Ramírez of Caguas, and others who belonged to the sugar patriots (patriotas azucareros) of the island, like Ramón B. Roig. According to the organization's constitution the members were colonos and landowners who had come together to promote their political projects and to protect their interests. The constitution stated that the goals of the Farmers Association were the following: to defend and protect the rights of the agrarian class; to foment unity and good relations between the agrarian classes; to improve the agriculture of the island and the 
conditions (social and material) of the laboring class; to work with the colonial government to develop a more just tax system; to foment the reform of the municipal government so the rural regions of the municipalities received necessary benefits (schools, roads, etc.); to reform the labor code on the island; to foment the establishment of agricultural cooperatives to disseminate information through the island; and to serve as intermediaries between the farmers and governmental departments. The Asociación also stated that, in order to avoid partisan pressure, it would not side with any political party (AAPR 1936:1-3).

By 1925 this organization counted 50 chapters, mostly in the sugar and tobacco municipalities, a membership of approximately 8,000, and a weekly publication, called El Agricultor Puertorriqueño (AAPR, junio 1924). Various factors led to the expansion of the newly formed organization. The economic conditions and governmental challenges that threatened the sugar industry on the island during the first years of the 1920 s were of great concern to the local sugar sector. At the mercy of the centrales and with the Unión unable to reform the colonial regime, the sugar sectors (colonos and centralistas) had no other option but to organize independently from the political parties in order to change the colonial structure. Records show that some of the leadership of the Farmers Association were members of Unión and Alianza. For example, the leadership of the organization included Unionista leaders such as Pablo Morales Cabrera, Manuel Zeno Gandía, and Eduardo Giorgetti. However, this was an uneasy relationship because these patriarchs never accepted the fusion of the Unionistas with the Republicanos in the Alianza.

Through the weekly publication El Agricultor Puertorriqueño, people like Giorgetti, Zeno Gandía and others expressed their frustrations with the government and the conditions of the island, but most of all they professed that the Farmers Association was going to defend Puerto Rican farmers. On December 12, 1925 Revista El Agricultor Puertorriqueño stated that Puerto Rican farmers were "the true owners of Puerto Rico even though until today they have served in the role of servants"(3-4). ${ }^{15}$ The landed classes of Puerto Rico understood the position they had played until that moment; however, in the 1920s the Puerto Rican landowners took a stance to put an end to foreign landownership and imperialist capitalism.

Among the local agrarian capitalists and landowners a corporatist approach to state management emerged, just as one was emerging in Cuba (Pérez 2003:173-174). According to Louis Pérez (2003:173), in the 1920s Cuban nationalist reformists "called for protection of national industry and commerce, agrarian reform, and a new governing relation between Cuba and the US." The Puerto Rican landed sectors hoped that 
through an alliance with commercial interests they could create a reformist block that would force the government to control oppositional groups antagonistic to their agricultural projects, especially those that promoted labor rights and an increase in the wages of agricultural workers. This move towards a more corporatist style of politics came about at a time when farmers blamed the professional classes within their parties for their emphasis on the Americanization, modernization and urbanization of the island. The Farmers Association felt that colonized bureaucrats, lawyers, and alcaldes (mayors) should be put in jail for stealing from the people (Revista El Agricultor Puertorriqueño, noviembre 30, 1928:23). This was also part of a reaction against the emerging professional classes (the core of the PRRep) who collaborated in the Americanization of Puerto Rico.

For the Fuerzas Vivas the emphasis placed on the liberal professions (e.g., law, medicine, etc.), and the Americanization project pushed by Republicanos and Socialistas were the cause of Puerto Rico's assumed loss of land. The Fuerzas Vivas argued that titles such as Doctor, Licenciado (lawyer) and Ingeniero (engineer) seduced men, especially young men. In order to reverse this trend the Fuerzas argued that people needed to return to "our common mother: the land" (Revista El Agricultor Puertorriqueño, mayo 8 , 1926:7) ${ }^{16}$ Behind this agrarian discourse laid the continuous struggle faced by the Puerto Rican landowners-to maintain their paternalistic grip over the labor force and to create favorable economic conditions to keep their dominant position in society.

Another aspect of the reformist agenda of the Farmers Association was a demand pushed by the landowners in 1924 to revise the school calendar. They wanted the calendar to follow the harvest schedule. They argued that the educational modernization brought by the American colonial masters was destabilizing the social hierarchy in the countryside. An educated peasant (campesino) population was challenging the power of the landowners by joining the FLT and demanding labor rights. The Fuerzas Vivas also wanted schools in the rural areas of the island to teach agricultural education and to reduce the number of high schools. For the Fuerzas Vivas, the rural child only needed a fourth grade education. They argued that it was good enough for the Puerto Rican child to learn how to read and write without giving him so much education that he became radicalized.

The agrarian discourse of the Fuerzas Vivas was one of purification. A coalition of titled colonial bureaucrats, foreigners, labor leaders and educated peasants who had united under the Coalición, they argued, had polluted Puerto Rico for the past thirty years. These political groups had tried to reform the colonial regime without any results except this pollution. Their quest to establish a modern democratic state had instead 
brought more problems to the island. For the Fuerzas Vivas, the United States could afford to establish a democracy, but Puerto Rico needed to follow a different path (Revista El Agricultor Puertorriqueño, abril 10, 1926:9).

In Caguas, the leading members of the Fuerzas Vivas belonged to the Caguas Agrarian League (Liga Agrícola de Caguas); all of them were colonos and were part of the most powerful families in the municipality. ${ }^{17}$ They were either members of the municipal government in 1924, had positions in the municipality in previous years, or were related to Assembly members by kinship. Furthermore, Manuel González Quiñones, a leading figure within the Fuerzas Vivas at the national level, represented the colonos cagüeños with his ties to the Quiñones Cabezudo family, and by holding the position of Secretary General of the Asociación de Agricultores.

After the Alianza victory in 1924 the colonos utilized the Agrarian League of Caguas, an affiliate of the Asociación de Agricultores Puertorriqueños, to push their agenda through the Municipal Assembly. The Agrarian League of Caguas became the legitimizing vehicle of the sugar sector and the Fuerzas Vivas in this municipality. The colonos began a series of meetings in the municipal government to confront the strikes in the sugar industry and to persuade the municipality to begin the construction of a series of roads to open new fields for sugar cultivation. Leading the meetings were the following elected officials: José B. Méndez, Miguel Quiñones Cabezudo, Oscar Lizardi, and Idelfonso Solá Morales, and the Agrarian League of Caguas leaders Miguel F. Chiqués, Francisco Solá, Salvador Rodríguez Ortiz and Cándido A. Ramírez. ${ }^{18}$ The meetings led to a series of demands by the colonos to improve and construct roads within the barrios of San Salvador and Borinquen. Salvador Rodríguez Ortiz and Francisco Solá requested that the Assembly speed up the public work projects in the barrios since these would benefit the laboring classes. The colonos presented the project as way to improve living conditions among workers who, according to them, were in miserable conditions. In addition, these new roads would allow them to work on planting sugar and tobacco. However, the real motive for the petition was to obtain access to virgin lands for the cultivation of sugar. The new roads would make the fields accessible to trucks. Furthermore, the value of those lands, as predicted by the colonos, would eventually increase (AHMC, Sección: Gobierno, Subsección: Alcalde, Serie: Correspondencia, Caja: 140, Años: 1919-1924). ${ }^{19}$ In Caguas, the assembly redistributed the government loan to help in the construction of the roads to farms owned by colonos in the barrios of Borinquen and San Salvador. The victory of the colonos and the Fuerzas Vivas in Caguas gave the illusion that the future was secure. 


\section{The End of Alianza's Domination}

The attacks and rhetoric of the Fuerzas Vivas was dividing the fragile alliance between PU and PRRep. The Fuerzas Vivas had to be seen as coalition of dissatisfied interests connected by their shared vision of a Puerto Rico in which the landed elite controlled the future of the island against urban bourgeois elements within Alianza and Coalición. In a memorandum the Fuerzas Vivas accused the Alianza of mismanaging the revenues generated from taxes, of inciting the agrarian classes of the island, and of becoming the main obstacle to private enterprise-that is, Puerto Rican private enterprise. In 1926 the Fuerzas Vivas began an attack against the Unionista leader Antonio R. Barceló. Enrique Landrón, leader of the Asociación de Agricultores, accused Barceló of being a socialist. Eduardo Giorgetti went so far as to publicly proclaim that for the next elections Puerto Rican farmers should organize under their own political party. This, according to Giorgetti, would stop Barceló's unprecedented actions.

Barceló responded forcefully to these allegations in several editorials in the Unionista newspaper, La Democracia. This Unionista leader stated that Landrón was a reactionary economist and that, like the Fuerzas Vivas, the Partido Unión and the Alianza were opposed to any form of Socialism. Within the Asociación de Agricultores there were those who supported Barceló. Francisco M. Zeno became the lone speaker for Barcelós cause in Fuerzas Vivas. Zeno argued that the Asociación de Agricultores should demand the enforcement of the 500-cuerdas law. The enforcement of this law, however, would have a tremendous impact on some of the members of Fuerzas Vivas such as Giorgetti, who was a centralista and powerful member of Partido Unión. Zeno clearly took the side of the small colono, of the small and medium landowner, and the tobacco farmer who constantly dealt with the banks, centrales, and the tobacco trusts from a disadvantaged position. At the same time Zeno argued that if Puerto Rico did not protect the agrarian sector, the island would lose the natural bearers of local culture. For Zeno, the colono, the jíbaro (mountain peasant), and the tobacco farmer, were "repositories of those cultural presuppositions that allegedly" held the essence of Puerto Rican identity. However, Zeno also saw the jíbaro as docile, ignorant, and obedient.

These views were representative of the Unionista, the Alianza and the Fuerzas Vivas mentality and it was at the core of the political project of this anti-colonial nationalism. Other intellectuals, such as Luis Muñoz Marín, argued that within the Asociación de Agricultores two distinct groups existed. One was the representative of the large corporation, the centralistas and large landowners, or what he called the "plutocracia", 
and on the other side were the colonos and the small farmers. He referred to the latter as the liberal tendency of the Fuerzas Vivas. According to Muñoz Marín the first group was destroying the second one and to survive they needed to leave the Fuerzas Vivas in order to unite under the leadership of the liberal faction of Barceló and Santiago Iglesias. Muñoz Marín saw the emerging fascist tendencies within the Fuerzas Vivas as anti-national and thought this was driving a wedge between the "legitimate" Puerto Ricans. ${ }^{20}$ In the attempt to formulate a new hegemonic process, the Fuerzas Vivas never legitimized or received subaltern support for their project, therefore losing out to the Alianza's project. In the elections of 1928, the Asociación de Agricultores toned down its rhetoric in exchange for several slots on the Alianza ballot. The election of 1928 was won by Alianza but this was a much closer contest than in 1924. Alianza obtained 132,113 votes and Coalición obtained 123,415 votes. Alianza defeated the Coalición once again but this victory was short-lived.

Looking at the municipal level we can begin to see how the Fuerzas Vivas began to put a strain on the fragile coalition and how partisanship began to affect local power contenders. In 1928, another series of controversies, much like those in 1924, threatened the power of the colonos and Alianza's control over Caguas. The controversy in Caguas revolved around the elected mayor, Pablo Héreter, a colono and member of the Agrarian League of Caguas. Héreter became the mayor of the municipality for Alianza at the same time the party was going through a series of internal fights. Disagreements with the Republicanos led to a struggle ending with Antonio Barceló declaring Alianza disbanded, although a minority in Alianza supported the continuation of the coalition. The associations of the Unionista majority of Caguas squarely put them with the pro-independence camp of Alianza. Advising this faction was Cayetano Coll y Cuchí. It was through Coll y Cuchí that Héreter received the notification that Barceló had declared the Partido Unión the leading party in Caguas. There was a Unionista minority, led by Félix Córdova Dávila, which still argued that Alianza was a party with all the powers it was vested with in 1924, including the power to nominate people for political offices.

The political struggles left a bitter taste for Héreter who decided to resign before his term began. Héreter supported the naming of fellow colonos and members of the Liga, José B. Méndez, Ulises Santiago and Idelfonso Solá Morales, but anti-Liga segments of the Alianza refused to accept these candidates. Unionistas in Caguas gave Méndez the majority of votes; however, he rejected the nomination. Santiago, who obtained the second largest number of votes, also rejected the nomination. This left Solá Morales as the candidate to substitute for Héreter. The 
minority, however, rejected Solá Morales as the mayor of Caguas. They in turn proposed a compromise and named Dr. José Reguero González mayor. Reguero González faced a hostile Assembly. Furthermore, Solá Morales decided to take his case to court where he hoped the judges would side with him as the selected candidate for the Partido Unión to substitute for Héreter.

Using Barcelo's argument that Alianza was no longer a political party, Solá Morales hoped to invalidate the nomination of Reguero González. The Unionistas in the assembly and followers of Solá Morales began a political war against the mayor. Solá Morales and Cayetano Coll y Cuchí led frequent meetings at the alcaldía to plot new strategies. One frequent strategy was to create rumors about Reguero González private life. The Unionistas would leak information about this candidate's many lovers and sexual escapades with less than decent women of Caguas. Politically, the Assembly formulated charges against the mayor's violation of municipal laws. Eventually, the assembly voted to declare the resignation of Pablo Héreter invalid and a letter was sent to him stating that he should resume his post as mayor. Héreter gladly accepted the request of the assembly (AHMC, Sección: Gobierno, Subsección: Asamblea Municipal, Serie: Actas, Años: 1929, Caja: sin numerar, Tomo: 11, Folio: 267, 268, 266; Tomo: 12, Folio: 59, 60, 239, 237, 279; Caja: 35; Años: 1929, Folio: 266, 269).

\section{Conclusions}

In 1929, the Alianza was dissolved and the agrarian, professional and commercial sectors of the island once again began to search for new roles in the colonial regime. Alianza failed because in the process of controlling and reforming the colonial regime from within through a coalition with the goal of removing militant labor as a potential rival to bourgeois reformism, the members of this coalition never overcame their own particular differences. The resurgence of political violence during the election of 1920 and 1924 was driven by several factors. First, it is clear that the Unionistas saw the Socialistas as a real threat to their political control over the island or at least throughout several districts, and this threat demonstrated that FLT and the Socialistas had broken the patriarchical control over the laboring groups in the island. The violence began during sugar worker strikes between 1915 and 1917. Out of these strikes a powerful pro-labor party emerges and this party in turn engenders a political conflict that would spill into the streets of Puerto Rico. Second, the political violence and partisanship of the 1920s resembles similar episodes at beginning of the century not because historical actors are behaving similarly to their predecessors, but to the contrary, 
because political violence and partisanship were and are deeply rooted in the island politics. The historical silence regarding this phenomenon is not due to an absence of political violence between the years of 1902 to 1915 or 1920 ; it has to do more with an absence of scholarly studies that focus on exploring this theme in the island. Further studies about the political behavior and clashes between different political factions may uncover many episodes that will explain how political violence and partisanship manifested itself during those years. Finally, it is clear that the political and economic transformations the island experienced during the years preceding the 1920s contributed to political reorganization of the established parties. The rapid expansion of the sugar industry, the growth of a powerful laboring organization, and the manipulation of the status of the island by the dominant parties were factors contributing to the sudden crisis the parties faced between 1920 and 1924. This crisis was exasperated by a colonial policy that was ambivalent, confusing, and contradictory. Furthermore, the local sugar industry dominated by local manufacturers and farmers suddenly was confronted by two powerful fronts: a pro-labor party that was restructuring its political platform by moving towards a more centrist position, and foreign capitalism that finally was breaking the local control over the sugar industry. Unwilling to give up their position, the landed sectors and those involved in the production of sugar from both dominant parties approached each other in order to create a new viable political organization that protected their interests.

Partisan politics continued to shape the political landscape even when elite-dominated parties united to defeat the surge of a political contender with strong labor support. The attacks delivered by party loyalists and leaders during the previous elections were never forgotten. Puerto Rican politics were and still are a contest between factions (in many cases political ones derived from a particular social class) who are trying to gain control over government. Parties mask their close class relations from their rank-and-file by constantly discussing the need to improve the living and economic conditions of the masses and by distracting them with lengthy debates over the political status of the island. Over time Puerto Rican political parties came to be defined by the stand each party took over the political status of the island. In this respect, present day political discourse has their beginnings in the 1920s when political contenders were forced to remake themselves and establish the status as the main issue while at the same time using jobs and political patronage as a form of political control. By focusing on such issues, the parties avoided discussing and formulating substantive political projects with real solutions for the island. 


\section{Notes}

I will like to thank Susan Rakow for help and comments on an earlier draft of this article. I will like to also thank Robert Shelton, Thomas Humphrey, Elizabeth Lehfeldt, and the anonymous readers from Caribbean Studies for their suggestions and comments. The research for this article was completed with the help of the Office of Sponsored Research and Programs, and the Office for Community and Minority Affairs at Cleveland State University, a fellowship from the David Rockfeller Center for Latin American Studies, and the Albert J. Beveridge Grant for Research in the History of the Western Hemisphere from the American Historical Association.

1 The Socialistas was the name given to the followers of the Socialist Party of Puerto Rico, and the Unionistas were the followers of the Unión Party.

2 For recent and not so recent scholarship see the works of César J. Ayala and Rafael Bernabe, Juan A. Giusti Cordero, Silvia Álvarez Curbelo, and Rafael A. Bernabe.

3 For a discussion of this term, Louis A. Pérez, Jr., Florencia Mallon, and the collection of essays by Gilbert Joseph, Catherine C. Legrand, and Ricardo Salvatore.

4 Up to 1920, Ángel Quintero Rivera's thesis of lucha triangular can be supported. According to Quintero Rivera, the lucha triangular evolved during the first decade of the twentieth-century as the political parties that represented the island during the late 1890s reorganized themselves to confront, collaborate or negotiate with the American colonial administration. These two parties were the Partido Republicano and Partido Unión (formerly known as Federal). The third component of this lucha triangular was the FLT. By 1920 with the numerical increase in the membership of the FLT and the rise of the Partido Socialista as a contender, the lucha triangular looses its validity or it needs to be restructured.

5 The supporters of the Unión were mostly the landed aristocracy with interest in the sugar, coffee and tabacco industries. In particular this party had among its leadership centralistas, and lawyers for the Sugar Corporations. The Republicanos attracted supporters from the emerging urban educated groups, members of the administrative groups working for the private enterprises, middle-class elements, and those who supported the incorporation of Puerto Rico as a state in the union. The Socialistas was composed elements from the different labor organizations on the island, in particular the Federación 
Libre de Trabajadores.

6 Unión's platform was driven by a liberal project in which liberty (rights of men, the right to free speech and assembly), equality (to all individuals) and fraternity (to eliminate prejudices) were at the core of their party's agenda.

7 These Socialistas shared the Assembly with Ambrosio Machuca Rodríguez, Manuel Bernardo, José B. Méndez, Miguel F. Chiqués, Antonio Vigo Aponte, Jesús Méndez Pereira and Domingo Lasa Quiñones.

8 Translation: si vuelves al trabajo mañana te voy a volar la tapa de los sesos por rompehuelgas.

9 García Casanova was the son of Gervasio García, the first elected mayor of Caguas under the American system.

10 Carta de la junta local de la Unión de Puerto Rico a la Asamblea municipal, fecha 14 de julio de 1924.

11 Carta de la Alianza Puertorriqueña Comité Local a la asamblea municipal, fecha julio 25, 1924.

12 See La Democracia, "Informe presentado ante la Asamblea de la Asociación de Agricultores..." and "Las fuerzas económicas y las fuerzas políticas," julio 13, 1925; "Ayer comenzó en Ponce la asamblea de Agricultores," diciembre 21, 1925. El Mundo, "Se pide una reunión...," and " Don Eduardo Giorgetti plantea estamos en plena crisis," diciembre 22, 1925. Asociación de Agricultores de Puerto Rico (hereafter AAPR), Llamando a las Filas (San Juan, PR.: Imprenta Venezuela, 1925), 7; Reece Bothwell and Lidio Cruz Monclova, "Manifiesto del Presidente del Partido Republicano José Tous Soto," in Los documentos, qué dicen? Vol. 1:1 (San Juan: Universidad de Puerto Rico, 1960), 434-435.

13 The principles of Alianza party can be found in Tous-Barceló manifest. See Bothwell and Cruz Monclova, "Manifiesto del Presidente del Partido Republicano José Tous Soto," 434-435, and Silvia Álvarez Curbelo, 148.

14 The Asociación Board of Directors were Pres. Antonio R. Matos (San Juan), 1er VP Consejero José L. Pesquera (San Juan), 2nd VP Consejero Carlos H. Blondet (Río Piedras), 3er VP Consejero Manuel A. García Méndez (Aguadilla), Tesorero Sandalio Torres Monje, Secretario Manuel González Quiñones, Sub Secretario Victor Fusté; Vocales: por acumulación: Antonio Tulla (Florida), por 
los agricultores: Rafael González Cuyar (Gurabo) y Juan Torruella Cortada (Ponce), por los agricultores de café: Eugenio Orsin (Mayagüez) y Ramón Dapena (Ponce), por los agricultores de tabaco: Antonio Colón Rivera (Comerío) y Ángel González (Juncos), por los agricultores de frutas citrosas: Enrique Landrón Jr. (Corozal) y Bert E. Stevenson (Bayamón), por los agricultores de cocos: Marcial Suárez (Río Grande) y Perfecto Rodríguez (Humacao), por los agricultores de algodón y frutos menores: Juan Santos Barreto (Arecibo) y Francisco López (Quebradillas), encargados de asuntos de contribuciones: Ramón B. Roig (San Juan).

15 Translation: los verdaderos dueños de Puerto Rico... aunque hasta hoy se hayan resignado con el desempeño del papel de siervos.

16 Translation: seno ubérrino de la madre común: la tierra.

17 These were José B. Méndez, Francisco Ramis, Marcos Jiménez, Domingo Lasa Quiñones, Oscar Lizardi, Onofre Solano, Francisco Solá, Pablo Héreter, Julio Janer, Idelfonso Solá Morales, Nicolás Quiñones Cabezudo, Cipriano Manrique Gil, Fernando and Antonio Guarch and Miguel F. Chiqués. This is only a partial list of the members. For a complete list see Liga Agrícola de Caguas, AGPR, Fondo: Departamento de Estado, Serie: Corporaciones sin fines lucrativos, caja: 15 A, Exp.: 200.

18 AHMC, Sección: Gobierno, Subsección: Asamblea Municipal, Serie: Actas, Caja: 34, Años: 1924-1925, Folio: 99, 100; Sección: Gobierno, Subsección: Alcalde, Serie: Correspondencia, Caja: 140, Años: 1919-1924; AGPR, Fondo: Departamento de Estado, Serie: Corporaciones sin fines lucrativos, Caja: 15 A, Exp.: 200.

19 However, the Assembly counted with a small group of individuals who were not controlled by the colonos. The colonos questioned the distribution of a $\$ 40,000$ government loan, by asking why road construction only received $\$ 10,000$. The rest of the loan was to be used for the construction of schools. Following the Fuerzas Vivas' class based educational philosophy, the colonos demanded the prioritization of road construction, not the building of schools with unnecessary luxury items. The students (that is peasant students), according to the colonos, did not need much since they should only be educated to the fourth grade.

20 See La Democracia , "El Sr. Barceló no se opone...," enero 4, 1926; "En la importante reunión...," junio 1, 1926; "Nos informa de Gurabo," junio 15, 1926; "Notas editoriales. El liberalismo de la Alianza," noviembre 11, 1926; "Notas editoriales. Lobos y corderos," 
julio 21, 1926; "Notas editoriales. Puñales mohosos," agosto 3, 1926; "Notas editoriales. El memorial de la Asociación de Agricultores," junio 8, 9, 11, 14, 1927; "Muñoz Marín habló el domingo a los obreros de Ponce," julio 6, 1926; “El Sr. Barceló no se opone...” enero 4, 1926; also see Partha Chatterjee, 158-159.

\section{References}

Álvarez Curbelo, Silvia. 1986-1987. "Un discurso ideológico olvidado: Los agricultores puertorriqueños (1924-1928).” Op. Cit. 2:141-160.

Andreu Iglesias, César.1998. Memorias de Bernardo Vega. Contribución a la historia de la comunidad puertorriqueña en Nueva York. San Juan: Ediciones Huracán.

Archivo Histórico Municipal de Caguas (AHMC). Sección: Gobierno, Subsección: Asamblea Municipal, Serie: Correspondencia, Caja: 18, Años: 1922-24.

Sección: Gobierno, Subsección: Asamblea Municipal, Serie: Correspondencia, Caja: 18, Años: 1922-24.

Sección: Gobierno, Subsección: Asamblea Municipal, Serie: Correspondencia, Caja: 18, Años: 1922-24. Carta de la junta local de la Unión de Puerto Rico a la Asamblea municipal, fecha 14 de julio de 1924.

Sección: Gobierno, Subsección: Asamblea Municipal, Serie: Correspondencia, Caja: 18, Años: 1922-24. Carta de la Alianza Puertorriqueña Comité Local a la asamblea municipal, fecha 25 julio de 1924.

. Sección: Gobierno, Subsección: Alcalde, Serie: Correspondencia, Caja: 140, Años: 1919-1924.

. Sección: Gobierno, Subsección: Asamblea Municipal, Serie: Actas, Caja: 34, Años: 1924-1925, Folio: 99, 100.

. Sección: Gobierno, Subsección: Asamblea Municipal, Serie: Actas, Años: 1929, Caja: 35, Folio: 266, 269.

Sección: Gobierno, Subsección: Asamblea Municipal, Serie: Actas, Años: 1929, Caja: sin numerar, Tomo: 11, Folio: 267, 268, 266.

Sección: Gobierno, Subsección: Asamblea Municipal, Serie: Actas, Años: 1929, Caja: sin numerar, Tomo: 12, Folio: 59, 60, 239, 237, 279.

Archivo General de Puerto Rico, Fondo: Departamento de Estado, Serie: Corporaciones sin fines lucrativos, Caja: 15 A, Exp.: 200.

. Asociación de Agricultores de Puerto Rico, Actas, Libro I, 27 de junio 1924, Folio: 173.

. Liga Agrícola de Caguas, Fondo: Departamento de Estado, Serie: Corporaciones sin fines lucrativos, caja: 15 A, Exp.: 200.

Asociación de Agricultores de Puerto Rico. 1925. Llamando a las Filas. San Juan, PR.: Imprenta Venezuela. 
Reglamento de la Asociación de Agricultores de Puerto Rico. 1936. San Juan, P.R.: La Asociación.

Ayala, César J. and Rafael A. Bernabe. 2007. Puerto Rico in the American Century: A History Since 1898. Chapel Hill: University of North Carolina.

Bernabe, Rafael A. 1996. Respuestas al colonialismo en la política puertorriqueña, 1899-1929. Río Piedras: Ediciones Huracán.

Bothwell González, Reece B. 1979. Puerto Rico: cien años de lucha política. Río Piedras: Editorial Universitaria, Universidad de Puerto Rico.

and Lidio Cruz Monclova. 1960. "Manifiesto del Presidente del Partido Republicano José Tous Soto.” Los documentos, qué dicen? Vol. 1:1. San Juan: Universidad de Puerto Rico.

Chatterjee, Partha. 1993 The Nation and Its Fragments: Colonial and Postcolonial Histories. Princeton, NJ: Princeton University Press.

García, Gervasio and Ángel G. Quintero Rivera. 1986. Desafío y solidaridad: Breve historia del movimiento obrero puertorriqueño. Puerto Rico: Ediciones Huracán.

Córdova, Gonzalo F. 1980. Santiago Iglesias Pantín: creador del movimiento obrero de Puerto Rico. Río Piedras: Editorial Universitaria.

El Mundo. 1922. "El Partido Unionista aprobó el sábado una resolución combatiendo al Gobernador E. Mont Reily," 25 de septiembre.

1922. "Última Hora, Córdova Dávila ha protestado nuevamente ante el Presidente de la continuación de Reily como Gobernador de Puerto Rico," 25 de septiembre.

.1925. "Se pide una reunión...," and " Don Eduardo Giorgetti plantea estamos en plena crisis," 22 de diciembre.

Giusti Cordero, Juan A. 1996. "En búsqueda de la nación concreta: El grupo español en la industria azucarera de Puerto Rico, 1898-1920s.” Pp. 211224 in La nación soñada: Cuba, Puerto Rico, Filipinas ante el 98, edited by Consuelo Naranjo, Miguel A. Puig-Samper and Luis Miguel García Mora. Madrid, Spain: Doce Calles.

Joseph, Gilbert, Catherine C. Legrand, and Ricardo Salvatore, eds. 1998. Close Encounter of Empire. Writing the Cultural History of U.S.-Latin American Relations. Durham: Duke University of Press.

La Democracia. 1920. "Programa de la Unión de Puerto Rico," 14 de septiembre. 1925. "Informe presentado ante la Asamblea de la Asociación de Agricultores...," julio 13. 1925. "Las fuerzas económicas y las fuerzas políticas," 13 de julio. 1925. "Ayer comenzó en Ponce la asamblea de Agricultores,” 21 de diciembre. 1926. "El Sr. Barceló no se opone...," 4 de enero. 1926. "En la importante reunión...," 1 de junio. 1926. "Nos informa de Gurabo," 15 de junio. 
6 de julio.

1926. "Muñoz Marín habló el domingo a los obreros de Ponce,"

1926. "Notas editoriales. Lobos y corderos," 21 de julio.

1926. "Notas editoriales. Puñales mohosos," 3 de agosto.

1926. "Notas editoriales. El liberalismo de la Alianza," 11 de noviembre.

. 1927. "Notas editoriales. El memorial de la Asociación de Agricultores," 8 de junio, pp. 9, 11, 14 .

Mallon, Florencia. 1995. Peasant and Nation. The Making of Post-Colonial Mexico. California: University of California Press.

National Archives and Records Administration, Record Group 350, 719-A, Entry 5, Box 112: Letter from Santiago Iglesias, President of the FLT to Samuel Gompers, President of the AFL, May 14, 1924.

Negrón-Portillo, Mariano. 1990. Las turbas republicanas, 1900-1904. Río Piedras: Ediciones Huracán.

Pagán, Bolívar. 1959. Historia de los partidos puertorriqueños, vol. 1. Spain: M. Pareja-Montaña.

Pérez, Jr., Louis A. 2003 [1990]. Cuba and the United States, Ties of Singular Intimacy. Athens: University of Georgia Press, $3^{\text {rd }}$ edition.

Programa del Partido Socialista de Puerto Rico. 1923. San Juan: Tip. Compañía Editora de "Justicia".

Quintero Rivera, Ángel G. 1973. "Background to the Emergence of Imperialist Capitalism in Puerto Rico." Caribbean Studies (13)3:31-63.

1974. "La clase obrera y el proceso político en Puerto Rico." Revista de Ciencias Sociales 18(1-2):145-200.

1974. "El capitalismo y el proletariado rural." Revista de Ciencias Sociales 18:(3-4):61-110.

. 1975. "El Partido Socialista y la lucha política triangular de las primeras décadas bajo la dominación norteamericana." Revista de Ciencias Sociales 29(1):47-100.

1978. Conflictos de clase política en Puerto Rico. Río Piedras: Ediciones Huracán.

1982. “Economía y política en Puerto Rico (1900-1934): Algunos elementos regionales-estructurales del crecimiento azucarero y el análisis de la política obrera." Presentation in the seminar "New Approaches to Puerto Rican History," Lehman College, New York.

1988. Patricios y plebeyos, burgueses, hacendados, artesanos y obreros: Las relaciones de clase en el Puerto Rico de cambios de siglo. Río Piedras: Ediciones Huracán.

Revista El Agricultor Puertorriqueño. 1926. "Es la democracia un obstáculo para un sistema de administración económico?," 1:18, abril 10:9.

1926. "La tierra se nos va," 1:22, mayo 8:7. 
Partisanship, Power Contenders ... in Puerto Rico, 1920s 35 1928. "Cooperatismo y mutualismo," 6:10, noviembre 3:23.

Scarano, Francisco A. 1993. Puerto Rico. Cinco siglos de Historia. New York: McGill Press.

Unión Obrera. 1920. "Caguas por los Socialistas,” octubre 14:2. 1920. "Turbas Unionistas en Caguas," octubre 21:3. 1920. "Elecciones en Caguas," noviembre 4:3. . 1921. "Minoría Socialista representada en Caguas," enero 20:2. 1921. "Huelguistas en Caguas...," marzo 24:3. 1921. "Notas de Caguas," julio 15:2. 